\title{
Characterization of the bound residues of the fungicide cyprodinil formed in plant cell suspension cultures of wheat ${ }^{\dagger}$
}

\author{
Melanie Sapp, Tanya Ertunç, Inken Bringmann, Andreas Schäffer and \\ Burkhard Schmidt* \\ Department of Biology V, RWTH Aachen University, D-52056 Aachen, Germany
}

\begin{abstract}
The non-extractable residues of the fungicide cyprodinil formed in heterotrophic cell suspension cultures of wheat were studied by application of $\left[2-\right.$ pyrimidyl- $\left.{ }^{14} \mathrm{C}\right]$ or $\left[2-\right.$ pyrimidyl $\left.-{ }^{13} \mathrm{C}\right]$ cyprodinil. The main objective was to examine whether solid-state and liquid ${ }^{13} \mathrm{C} N M R$ spectroscopy can be used to examine plant bound residues of pesticides. For ${ }^{14} \mathrm{C}$ experiments, wheat suspensions grown on glucose as carbon source were treated with $10 \mathrm{mglitre}^{-1}$ of ${ }^{14} \mathrm{C}$-cyprodinil. After incubation for 12 days, $20 \%$ of applied ${ }^{14} \mathrm{C}$ was detected as non-extractable residues. The cell debris were treated with $0.1 \mathrm{M} \mathrm{HCl} \mathrm{(reflux),}$ $1.0 \mathrm{M} \mathrm{HCl}$ (reflux), buffer, or $2 \mathrm{M} \mathrm{NaOH}\left(50^{\circ} \mathrm{C}\right)$; Björkman lignin and acidolysis lignin fractions were also prepared from the debris. Radioactivity liberated and solubilized by these procedures was examined by thin-layer chromatography and high-performance liquid chromatography. The results showed that cyprodinil and primary metabolites contributed to the fungicide's bound residues. Most of the residues $\left(12 \%\right.$ of applied $\left.{ }^{14} \mathrm{C}\right)$ remained associated with polar or polymeric/oligomeric endogenous cell materials in a stable manner. For the study with ${ }^{13} \mathrm{C}$-cyprodinil, wheat suspensions were cultivated on ${ }^{13} \mathrm{C}$-depleted glucose for four growth cycles, resulting in maximum ${ }^{13} \mathrm{C}$ depletion of the natural cell components to about $0.10 \%$. During the fourth cycle, ${ }^{13} \mathrm{C}$-labelled cyprodinil was applied, and cells were incubated (12 days). Cell debris was prepared and examined by solid-state ${ }^{13} \mathrm{C}$ NMR spectroscopy. Debris was then treated as described above in the ${ }^{14} \mathrm{C}$ experiment. Solubilized fractions were analyzed by liquid ${ }^{13} \mathrm{C}$ NMR spectroscopy. However, none of the ${ }^{13} \mathrm{C}$ NMR spectra recorded gave utilizable or unambiguous results, and all exhibited large inconsistencies, especially concerning the data from the conventional ${ }^{14} \mathrm{C}$ experiment. (c) 2003 Society of Chemical Industry
\end{abstract}

Keywords: cyprodinil; fungicide; non-extractable residues; fractionation; ${ }^{13} \mathrm{C}$ NMR spectroscopy; ${ }^{13} \mathrm{C}$ depletion

\section{INTRODUCTION}

Following their application to plants, pesticides can give rise to extractable residues, consisting of unchanged pesticide and/or its primary metabolites and conjugates of such metabolites, and (nonextractable) bound residues. The latter are usually insoluble in organic and aqueous solvents, and result from a number of types of binding. Such residues can be detected and quantified only by using radioactive (mainly ${ }^{14} \mathrm{C}$-) labelled compounds. Thus, non-extractable pesticide residues in plants are characterized by experimental procedures utilized for their detection, quantification and fractionation rather than by clear-cut chemical or physicochemical structures. The first definition of bound residues in plants was published about 20 years ago in a IUPAC Pesticide Commission Report. ${ }^{1,2}$
Other, similar, approaches were published later. ${ }^{3-8}$ Accordingly, the term non-extractable residues is employed to identify the fraction of (pesticide-derived) radioactivity remaining in the plant residuum (debris) after application of (exhaustive) extraction procedures, which, however, do not significantly alter the chemical nature of these residues. Bound residues can be formed from both intact pesticides and their metabolites, but exclude (eco-) toxicologically irrelevant fragments recycled into natural polymeric plant products. In all studies concerned with non-extractable residues, proportions of these residues should be given together with the extraction procedure used.

During pesticide registration, the toxicological significance of the chemical's residues in edible portions of the crop following treatment as prescribed has to be evaluated if certain trigger values are exceeded

* Correspondence to: Burkhard Schmidt, Department of Biology V, RWTH Aachen University, Worringerweg 1, D-52056 Aachen, Germany E-mail: burkhard.schmidt@post.rwth-aachen.de

${ }^{\dagger}$ Based on a presentation at the 10th IUPAC International Congress on the Chemistry of Crop Protection: Innovative Solutions for Healthy Crops, held on 4-9 August, 2002, in Basel, Switzerland

Contract/grant sponsor: Deutsche Forschungsgemeinschaft; contract/grant numbers: Scha 390/2-1, Scha 390/2-2

(Received 10 June 2003; revised version received 12 July 2003; accepted 22 July 2003)

Published online 3 November 2003 
(see below). Pesticide residues include the parent, its soluble primary metabolites and conjugates, and also bound residues. From a regulatory standpoint, the significance of non-extractable pesticide residues is primarily a consideration of their amount, location in the plant, and their character. In the EU, trigger values for the evaluation of residues in general are $10 \%$ of the total ${ }^{14} \mathrm{C}$ detected or $0.05 \mathrm{mg} \mathrm{kg}^{-1}$, depending, however, on their respective toxicities. ${ }^{9-11}$ Comparable values hold true for the USA. ${ }^{6,12,13}$ Above these trigger values, residues have to be characterized and evaluated. In the case of bound residues, this may imply the use of accelerated extraction methods (eg supercritical fluid extraction, microwave-assisted extraction), chemical treatment with acids and bases, sequential fractionation procedures, as well as enzymatic digestion. ${ }^{1,4-6,9,11,13}$ Findings from these procedures together should render possible the evaluation of the bioavailability of potentially toxic pesticidal moieties in humans and animals. However, extracted plant materials as well as associations between pesticidal structures and insoluble plant components exhibit a great complexity. Most often, data on the bioavailability of bound residues are determined in feeding studies using laboratory animals, and are only complemented by a few less time-consuming characterization methods, such as acid and base treatment. ${ }^{1,3,4,14,15}$

Nevertheless, a number of studies executed in the past aimed at the exploration of the chemical and physico-chemical nature of bound pesticides residues in plants. Interest came both from an academic viewpoint and from increased demands for pesticide safety regarding human health and environment. ${ }^{1,14,16-20}$ It was shown that pesticidal moieties can be associated with every plant polymer (ie protein, polysaccharides, cellulose, hemicellulose, pectin, lignin, starch, cutin), and that associations may result from covalent bonds, physico-chemical interactions and entrapment into three-dimensional plant polymers, such as lignin. Valuable information was derived particularly from sequential fractionation procedures using chemical and/or enzymatic treatments of the extracted plant residuum, ${ }^{14,16,18}$ although, depending on the plant material used, not all of the studies were successful in affording unequivocal results. ${ }^{14,19}$

In the present paper, we report the characterization of non-extractable residues of the anilinopyrimidine fungicide cyprodinil arising in plant cell suspension cultures of wheat by conventional methods and by solid-state and liquid ${ }^{13} \mathrm{C}$ NMR spectroscopy. Cyprodinil, introduced by Ciba-Geigy (now Syngenta) in 1993 is used in wheat and other crops. ${ }^{21-23}$ Some details of its metabolism in plants were published but further results pointed to significant portions of non-extractable residues. ${ }^{24,25}$ Soil-bound residues of ${ }^{13} \mathrm{C}$-cyprodinil were recently examined by ${ }^{13} \mathrm{C}$ NMR spectroscopy and the experiments gave useful results. ${ }^{26,27}$ Solid-state and liquid ${ }^{13} \mathrm{C}$ NMR spectroscopy are frequently employed to study structures of plant polymers, such as lignin and cellulose. ${ }^{28-31}$ The usefulness of plant cell cultures as in vitro model systems for studies on the metabolism of pesticides in plants has been demonstrated in a number of investigations. ${ }^{32}$ In detail, the aims of the present study were to ascertain, whether ${ }^{13} \mathrm{C}$ NMR spectroscopy can be employed to examine the bound residues of ${ }^{13} \mathrm{C}$-labelled cyprodinil formed in plant cell suspension cultures of wheat, and whether data resulting from ${ }^{13} \mathrm{C}$ NMR spectroscopy can be correlated with those obtained using conventional methods. The study was part of a larger project concerned with the applicability of ${ }^{13} \mathrm{C}$ NMR spectroscopy to the analysis of non-extractable residues of cyprodinil in plant tissues; corresponding results will be published in the future.

\section{MATERIALS AND METHODS}

\subsection{Labelled and non-labelled chemicals}

The chemical structure of cyprodinil (CGA 219 417; 4-cyclopropyl-6-methyl- $N$-phenylpyrimidin-2-amine) is given in Fig 1. [2-pyrimidyl- $\left.{ }^{14} \mathrm{C}\right]$ Cyprodinil, specific activity: $421.31 \mathrm{MBq} \mathrm{mmol}^{-1}$, radiochemical purity $98 \%$ as determined by HPLC, [2-pyrimidyl-

$\left.{ }^{13} \mathrm{C}\right]$ cyprodinil and authentic reference samples of non-labelled cyprodinil and its metabolites M1 to M11 (Fig 1) were generous gifts of Novartis Crop Protection AG, now Syngenta (Basel, Switzerland). For the metabolism experiments, application solutions were prepared in methanol; volumes used for application were between $15 \mu \mathrm{l}$ and $50 \mu \mathrm{l}$ per assay. D- $\left[{ }^{12} \mathrm{C}_{6}\right] \mathrm{Glu}-$ cose $\left({ }^{13} \mathrm{C}\right.$-depleted; 99.9 atom $\left.\%{ }^{12} \mathrm{C}\right)$ was supplied by Chemotrade (Leipzig, Germany).

\subsection{Cell cultures and treatments}

For the metabolism experiments, cell suspension cultures of wheat (Triticum aestivum L cv 'Heines Koga II') were used, which were routinely grown on<smiles>[R]c1ccc(Nc2nc(C)cc(C3CC3)n2)cc1[R]</smiles>

$\mathrm{R}_{1}=\mathrm{H}, \mathrm{R}_{2}=\mathrm{H}$ : cyprodinil

$\mathrm{R}_{1}=\mathrm{S}(\mathrm{O}) \mathrm{CH}_{2} \mathrm{CHOHCOOH}, \mathrm{R}_{2}=\mathrm{OH}: \mathbf{M} 1$

$\mathrm{R}_{1}=\mathrm{SCH}_{2} \mathrm{CHOHCOOH}, \mathrm{R}_{2}=\mathrm{OH}: \mathbf{M} 2$

$\mathrm{R}_{1}=\mathrm{H}, \mathrm{R}_{2}=\mathrm{OH}: \mathbf{M} 3$

$\mathrm{R}_{1}=\mathrm{OH}, \mathrm{R}_{2}=\mathrm{H}: \mathbf{M} \mathbf{4}$

$\mathrm{R}_{1}=\mathrm{SCH}_{2} \mathrm{CHNH}_{2} \mathrm{COOH}, \mathrm{R}_{2}=\mathrm{H}: \mathrm{M} 11$<smiles>[R6]c1nc(Nc2ccccc2)nc(C2CC2)c1[R6]</smiles>

$\mathrm{R}_{3}=\mathrm{CH}_{3}, \mathrm{R}_{4}=\mathrm{OH}: \mathbf{M} \mathbf{5}$

$\mathrm{R}_{3}=\mathrm{CH}_{2} \mathrm{OH}, \mathrm{R}_{4}=\mathrm{H}: \mathbf{M 8}$

$\mathrm{R}_{3}=\mathrm{COOH}, \mathrm{R}_{4}=\mathrm{H}: \mathrm{M} 10$<smiles>Bc1cc(C2CC2)nc(C)n1</smiles>

$\mathrm{R}_{5}=\mathrm{NH}_{2}: \mathbf{M 6}$

$\mathrm{R}_{5}=\mathrm{OH}: \mathbf{M} 7$<smiles>N=C(N)Nc1ccccc1</smiles>

M9

Figure 1. Chemical structures of cyprodinil and its metabolites M1 to M11. 
B5 medium supplemented with glucose $\left(20 \mathrm{glitre}^{-1}\right)$ as carbon source. Maintenance of the suspensions was performed essentially as described previously. ${ }^{32}$ The cultures were derived from cell suspensions which had also been grown on B5 medium containing sucrose $\left(20 \mathrm{~g} \mathrm{litre}^{-1}\right) .^{32}$ For adaptation, inoculum ( $\left.c a 1 \mathrm{~g}\right)$ of these cells was introduced into B5 medium containing glucose instead of sucrose. After 10 growth cycles (14 days per cycle), fresh weight yields obtained after a complete cycle had returned to adequate levels (about $2.4 \mathrm{~g}$ per assay). Judged from their outer appearance, the cultivated cells were in good condition.

Experiment 1 was performed using wheat suspensions which were grown on glucose containing the natural ${ }^{12} \mathrm{C} /{ }^{13} \mathrm{C}$-ratio. On day 7 of the growth cycle, the cultures (20 replicates) were treated with ${ }^{14} \mathrm{C}$ cyprodinil ( $10 \mathrm{mg}$ litre $^{-1}, 35 \mathrm{kBq}, 200 \mu \mathrm{g}$ per assay) and incubated for 12 days. Experiment 2 was executed in a similar manner except that ${ }^{14} \mathrm{C}$-cyprodinil was applied to five replicates at $200 \mu \mathrm{g}, 350 \mathrm{kBq}$ per assay. These assays were utilized as ${ }^{14} \mathrm{C}$ controls for the study with ${ }^{13} \mathrm{C}$-cyprodinil (experiment 3 ).

For experiment 3, an appropriate number of wheat suspensions were grown and multiplied on $\mathrm{D}-\left[{ }^{12} \mathrm{C}_{6}\right]$ glucose for three growth cycles. The suspensions were then subcultivated in medium containing D$\left[{ }^{12} \mathrm{C}_{6}\right]$ glucose, resulting in 25 replicates. After 7 days, 24 replicates were treated with ${ }^{13} \mathrm{C}$-cyprodinil $(200 \mu \mathrm{g}$ per assay), while one assay remained untreated. All assays were incubated as described before. The untreated assay was used for the determination of the ${ }^{13} \mathrm{C} /{ }^{12} \mathrm{C}$ ratio $\left({ }^{13} \mathrm{C}\right.$ depletion), and for the examination by solid-state ${ }^{13} \mathrm{C}$ NMR.

\subsection{Extraction and fractionation of material from experiments 1 and $2\left({ }^{14} \mathrm{C}\right.$-cyprodinil)}

In general, cells and media were separated by vacuum filtration. The cells from each assay were added in methanol + water $(8+2$ by volume; ca $20 \mathrm{ml})$ and stored for $48 \mathrm{~h}$ at $-20^{\circ} \mathrm{C}$. Subsequently, cells were extracted by sonication (Bandelin; Berlin, Germany) and the extraction mixture was centrifuged $(5000 \mathrm{~g}$, $15 \mathrm{~min}$ ). The supernatant was decanted and passed through a paper filter (vacuum filtration). Extraction was repeated once and, finally, the entire cell debris were collected on the filter.

\subsubsection{Experiment 1}

Filter paper and adhering cell debris from three assays were air-dried and combusted in a biological oxidizer OX 500 (Zinsser/Harvey Instruments, Frankfurt, Germany) in order to determine proportions of nonextractable residues. Cell debris from the remaining 17 assays was collected from filter papers, combined, air-dried and stored under argon at $-20^{\circ} \mathrm{C}$ : the filter papers used in the assays and three samples ( $c a 60 \mathrm{mg}$ each) of air-dried cell debris were combusted. Defined samples $(75-200 \mathrm{mg}$ ) of the air-dried cell debris were subjected to the following procedures. ( $\mathrm{i}$ and ii) Samples were refluxed in hydrochloric acid $(0.1 \mathrm{M}$ or
$1 \mathrm{M})$ for $30 \mathrm{~min},{ }^{33}$ after which reaction mixtures were centrifuged $(5000 \mathrm{~g}, 5 \mathrm{~min})$ and supernatants were removed and extracted with ethyl acetate. (iii) Samples were suspended in dioxane + water $(9+1$ by volume) and stirred at $22^{\circ} \mathrm{C}$ for 7 days (Björkman lignin). ${ }^{18}$ After centrifugation $(5000 \mathrm{~g}, 45 \mathrm{~min})$, supernatants were extracted with ethyl acetate. (iv) Samples were suspended in dioxane $+2 \mathrm{M}$ hydrochloric acid $\left(9+1\right.$ by volume) and heated at $70^{\circ} \mathrm{C}$ for $5 \mathrm{~h}$ (acidolysis lignin); ${ }^{18}$ mixtures were then centrifuged ( $5000 \mathrm{~g}, 45 \mathrm{~min}$ ), and supernatants were extracted with ethyl acetate. (v) Samples were stirred in potassium phosphate buffer $(50 \mathrm{mM}, \mathrm{pH} 7)+$ methanol $(99+1$ by volume) for 2 days at $22^{\circ} \mathrm{C},{ }^{18}$ after which reaction mixtures were extracted with ethyl acetate.

\subsubsection{Experiment 2}

Cell debris samples with non-extractable ${ }^{14} \mathrm{C}$ were collected, treated and stored as described above. Filter paper and total adhering cell debris from one assay were combusted. Samples of the air-dried cell debris were subjected to procedures i, ii, iii, iv or $\mathrm{v}$ as described in Section 2.3.1. Additionally, samples of the debris were subjected to procedure vi in which samples were suspended in sodium hydroxide solution $(2 \mathrm{M})$ and heated at $50^{\circ} \mathrm{C}$ for $2 \mathrm{~h} .{ }^{34}$ The reaction mixture was then neutralized (hydrochloric acid) and extracted (ethyl acetate), or subjected to SPE $\left(\mathrm{C}_{18^{-}}\right.$ Chromabond; Macherey-Nagel; Düren, Germany) completed by elution with methanol. All extracts were analyzed by TLC and HPLC for cyprodinil and its metabolites.

\subsection{Extraction and fractionation of material from experiment $3\left({ }^{13} \mathrm{C}\right.$-cyprodinil)}

Separation of media and cells as well as extraction of cells was performed as described above. The average fresh weight of the cells was $3.28 \mathrm{~g}$ per assay. Cell debris resulting after extraction was collected from filter papers, combined, air-dried and stored under argon at $-20^{\circ} \mathrm{C}$. A sample (ca $150 \mathrm{mg}$ ) of the debris was examined directly by solid-state ${ }^{13} \mathrm{C}$ NMR; cell debris prepared from untreated ${ }^{13} \mathrm{C}$-depleted cells was similarly analyzed. Samples $(60-500 \mathrm{mg})$ of the debris subsequently derived from the cyprodinil-treated cells were subjected to procedures ii, iii, iv, $\mathrm{v}$ and vi (SPE modification) as described above. The following samples were prepared for ${ }^{13} \mathrm{C}$ NMR: (ii) ethyl acetate extract and remaining aqueous phase (individually), both dissolved in methanol- $d_{4}$, (iii) ethyl acetate extract and aqueous phase (combined), dissolved in 1,4-dioxane- $d_{8}+\mathrm{D}_{2} \mathrm{O}(9+1$ by volume); (iv) same as (iii); (v) ethyl acetate extract and aqueous phase (individually), both dissolved in $\mathrm{D}_{2} \mathrm{O}$; (vi) methanol eluate, dissolved in methanol- $d_{4}+\mathrm{D}_{2} \mathrm{O}(95+5$ by volume). For preparation of ${ }^{13} \mathrm{C}$ NMR samples, extracts and corresponding aqueous phases were concentrated under vacuum, and remaining residues were dissolved in the respective deuterated solvent. The latter was again evaporated; this process was 
repeated twice. Residues were then finally dissolved in respective deuterated solvents.

\subsection{Analytical procedures}

Thin-layer chromatography (TLC) was performed on silica gel plates SIL G-25 UV $\mathrm{UV}_{254}(0.25 \mathrm{~mm}$; Macherey-Nagel, Düren, Germany) using chloroform + methanol + formic acid + water $(90+10+4+1$ by volume) as solvent system. Separated ${ }^{14} \mathrm{C}$ peaks were located and quantified using a Tracemaster 40 radiochromatogram scanner (Berthold, Wildbad, Germany) or a Fuji BAS 1000 Bio-Imaging Analyzer and BAS-MS Imaging Plates (Raytest, Straubenhardt, Germany). Non-labelled cyprodinil and metabolites were detected using UV light $(254 \mathrm{~nm})$.

High-performance liquid chromatography (HPLC) was executed using a Hewlett-Packard Series 1100 system connected to a Ramona 2000 radioisotope detector (Raytest, Straubenhardt, Germany). The system was equipped with a ET 250/4 Nucleosil 100-5 C18 column (length: $250 \mathrm{~mm}$, diameter: $4 \mathrm{~mm}$; Macherey-Nagel, Düren, Germany) and operated at $20^{\circ} \mathrm{C}$ with a flow of $0.8 \mathrm{ml} \mathrm{min}{ }^{-1}$. Non-labelled cyprodinil and its metabolites were detected at 254, 270 and $290 \mathrm{~nm}$, respectively. Elution was carried out with solvents A (potassium phosphate buffer, $10 \mathrm{mM}$, $\mathrm{pH}$ 7.5) and $\mathrm{B}$ (methanol) as follows: isocratic $\mathrm{A}+\mathrm{B}$ $(8+2$ by volume) for $2 \mathrm{~min}$, followed by a linear 35 min gradient to $\mathrm{A}+\mathrm{B}(2+8$ by volume $)$, isocratic $\mathrm{A}+\mathrm{B}(2+8$ by volume $)$ for $14 \mathrm{~min}$, and return to initial conditions within $4 \mathrm{~min}$. All HPLC analysis were terminated by washing the column for $5 \mathrm{~min}$ using $\mathrm{A}+\mathrm{B}(8+2$ by volume $)$. The injection volume was $100 \mu \mathrm{l}$. All solvents and samples to be analyzed were filtered $(0.2 \mu \mathrm{m})$.

Remaining necessary radioanalysis (LSC, combustion) was executed using standard equipment and procedures.

\section{$2.6{ }^{13} \mathrm{C}$ NMR spectroscopy}

Liquid, proton-decoupled (WALTZ) ${ }^{13} \mathrm{C}$ NMR spectra were recorded at $75.5 \mathrm{MHz}$ on a Bruker AC300 NMR spectrometer (Karlsruhe; Germany) using $10 \mathrm{~mm}$ (Wilmad 'Ultra-Imperial') NMR-tubes (Spintec; Remshalden, Germany). The parameters for measurement were: spectral width: $17857.143 \mathrm{~Hz}$; number of data points collected: 32768 ; centre of spectrum: $300.13 \mathrm{MHz} ; 30^{\circ}$ pulse (length: $0.3 \mu \mathrm{s}$ ); relaxation delay: $1.0 \mu \mathrm{s}$; pulse delay: $37.5 \mu \mathrm{s} .{ }^{13} \mathrm{C}$ Spectra of [2-pyrimidyl- $\left.{ }^{13} \mathrm{C}\right]$ cyprodinil and its nonlabelled metabolites were obtained after several hundred scans, respectively, whereas the samples derived from the ${ }^{13} \mathrm{C}$ metabolism study were examined for 45000 scans. Chemical shifts were recorded in $\mathrm{ppm}$ relative to tetramethylsilane $(0 \mathrm{ppm})$. Solidstate, high-power proton-decoupled (WALTZ) ${ }^{13} \mathrm{C}$ NMR (CP/MAS) were recorded on a Bruker Advance DSX 500 NMR spectrometer at $125.80 \mathrm{MHz}$ using a $7 \mathrm{~mm} \mathrm{ZrO}_{2}$ rotor (Bruker, Karlsruhe, Germany). The parameters for measurement were: contact time:
$2.5 \mathrm{~ms}$; MAS: $5 \mathrm{kHz}$; pulse length: $1.5 \mu \mathrm{s}$; relaxation delay: $5 \mathrm{~s}$; proton field: $500.45 \mathrm{MHz}$. Before the measurements, the NMR spectrometer was calibrated externally using adamantane. Spectra of samples originating from the ${ }^{13} \mathrm{C}$ metabolism study were derived from a total of 2500 scans.

\subsection{Determination of the ${ }^{13} \mathrm{C} /{ }^{12} \mathrm{C}$ ratio $\left({ }^{13} \mathrm{C}\right.$ depletion)}

Samples of wheat cells derived from the different stages of ${ }^{13} \mathrm{C}$ depletion were extracted as described before. Remaining cell debris was lyophylized and stored under argon at $-20^{\circ} \mathrm{C}$. The following procedures were kindly performed by Mrs A Seraphin at the Institute of Hydrobiology and Fishery Science (University of Hamburg, Germany) in accordance with an established method (Ertl S and Spitzy A, 2003, pers comm). In short, three replicate samples were decarbonized with hydrogen chloride vapour. Remaining organic carbon was reacted to give carbon dioxide and subjected to high-resolution mass spectrometry using a MAT 252 (ThermoFinnigan; Egelsbach, Germany). Commonly, ${ }^{13} \mathrm{C}$ depletion is expressed by the $\delta^{13}$ value which is calculated according to

$\delta^{13}=\left\{\left[\left({ }^{13} \mathrm{C} /{ }^{12} \mathrm{C}\right)_{\text {sample }} /\left({ }^{13} \mathrm{C} /{ }^{12} \mathrm{C}\right)_{\text {natural }}\right]-1\right\} 1000 \%$.

Natural ${ }^{13} \mathrm{C} /{ }^{12} \mathrm{C}$-ratio and complete ${ }^{13} \mathrm{C}$ depletion correspond with $\delta^{13}=0$ and $\delta^{13}=-1000$, respectively.

\section{RESULTS AND DISCUSSION}

\subsection{Optimization of the experimental design}

In the authors' laboratory, pesticide metabolism studies using wheat cell suspensions are always performed under standardized conditions, ie with application of $20 \mu \mathrm{g}\left(1 \mathrm{mg}\right.$ litre $\left.^{-1}\right)$ of the compound per assay and $48 \mathrm{~h}$ of incubation ending with the growth cycle of the cultures. ${ }^{32}$ Usually, the wheat cells are grown heterotrophically on natural sucrose as carbon source. ${ }^{32}$ In preliminary experiments (results not shown) executed with ${ }^{14} \mathrm{C}$-labelled cyprodinil under these conditions, about $2 \mu \mathrm{g}$ of bound residues per assay (based on parent fungicide) were obtained. However, the residues were present in about $200 \mathrm{mg}$ of the cell debris (with natural ${ }^{13} \mathrm{C} /{ }^{12} \mathrm{C}$ ratio), which remained after extraction of the cells. These findings were considered as insufficient for the intended metabolism and ${ }^{13} \mathrm{C}$ NMR studies with ${ }^{13} \mathrm{C}$-labelled cyprodinil, especially regarding the ratio between ${ }^{13} \mathrm{C}$ derived from bound residues of the fungicide and natural (interfering) ${ }^{13} \mathrm{C}$ contained in insoluble cell components.

In order to increase this ratio, three modifications of the standardized procedure were made; ultimately, these resulted in a decrease in the content of ${ }^{13} \mathrm{C}$ in the case of the insoluble plant cell components, and higher levels of the bound residues of cyprodinil. 
First, the wheat cells were adapted to glucose over a period of 10 growth cycles. This modification was necessary, since ${ }^{13} \mathrm{C}$-depleted glucose-but not sucrose - was commercially available. Second, using the glucose-adapted cells and ${ }^{14} \mathrm{C}$-labelled cyprodinil, timing of application and incubation interval were optimized regarding maximum portions of the nonextractable residues of the compound. Third, the amount of cyprodinil applied was increased to $200 \mu \mathrm{g}$ $\left(10 \mathrm{mg}\right.$ litre $\left.^{-1}\right)$ per assay to obtain maximum amounts of bound residues. For the final experiment with ${ }^{13} \mathrm{C}$-cyprodinil, glucose-adapted wheat cells were cultivated on media containing ${ }^{13} \mathrm{C}$-depleted glucose for four growth cycles. The ${ }^{13} \mathrm{C}$ fungicide was applied during the fourth cycle; both, application and incubation were executed under optimized conditions.

\subsection{Experiments 1 and 2 with ${ }^{14} \mathrm{C}$-cyprodinil}

Using the glucose-adapted wheat cells, two metabolism experiments were performed with [2-pyrimidyl${ }^{14} \mathrm{C}$ ]cyprodinil. Experiment 1, carried out prior to the study with ${ }^{13} \mathrm{C}$-cyprodinil, was considered to provide conclusive verification for optimum experimental conditions regarding the formation of non-extractable residues. In experiment 2, cyprodinil exhibiting a higher specific activity was employed. This study was executed parallel to the experiment with ${ }^{13} \mathrm{C}$ labelled cyprodinil and served as ${ }^{14} \mathrm{C}$ support for these assays concerning treatments and fractionation of the fungicide's non-extractable residues.

The distributions of radioactivity observed in experiments 1 and 2 after termination of incubation are displayed in Table 1. Similar results were obtained in both experiments. Most of the radioactivity was detected in the cells, while 20.35 and $20.10 \%$, respectively, of applied ${ }^{14} \mathrm{C}$ remained non-extractable with cellular debris, consequently amounting to about $40 \mu \mathrm{g}$ of bound residues per assay (based on parent). Compared with the standardized conditions $(2 \mu \mathrm{g}$ of bound residues per assay), a 20-fold increase in cyprodinil-derived non-extractable residues was thus

Table 1. Distribution of radioactivity after termination of metabolism experiments $1^{\mathrm{a}, \mathrm{c}}$ and $2^{\mathrm{b}, \mathrm{c}}$

\begin{tabular}{lcc}
\hline Fraction & $\begin{array}{c}\text { Experiment 1 } \\
(\%)\end{array}$ & $\begin{array}{c}\text { Experiment 2 } \\
(\%)\end{array}$ \\
\hline Media & 25.28 & 24.72 \\
Cell extracts & 59.67 & 48.34 \\
Non-extractable residues ${ }^{d}$ & 20.35 & 20.10 \\
Recovered ${ }^{14} \mathrm{C}^{\mathrm{d}}$ & 105.30 & 93.16 \\
Recovered ${ }^{14} \mathrm{C}$-cyprodinile & 5.50 & 4.16 \\
\hline
\end{tabular}

a $200 \mu \mathrm{g}, 35 \mathrm{kBq}$ of ${ }^{14} \mathrm{C}$-cyprodinil per assay; 20 replicates; average fresh weight yield per assay: $2.68 \mathrm{~g}$.

b $200 \mu \mathrm{g}, 350 \mathrm{kBq}$ of ${ }^{14} \mathrm{C}$-cyprodinil; five replicates; average fresh weight yield per assay: $2.66 \mathrm{~g}$.

${ }^{c}$ Average values in $\%$ of applied ${ }^{14} \mathrm{C}$ are shown.

d Non-extractable residues were determined by combustion of three assays (experiment 1) and one assay (experiment 2).

e Portions of ${ }^{14} \mathrm{C}$-cyprodinil remaining after incubation intervals were determined with TLC of individual media and cell extracts. achieved. In experiments 1 and 2, only minor portions of non-metabolized cyprodinil were recovered after $48 \mathrm{~h}$ of incubation; this finding points to high turnover of the fungicide in the adapted wheat cells.

Portions of the non-extractable residues of cyprodinil resulting from the experiments 1 and 2 were determined by combustion of products of only three assays and one assay, respectively. Insoluble cell debris of the remaining assays of each experiment were combined and then subjected to particular treatments in order to examine whether ${ }^{14} \mathrm{C}$ associated with the cell debris could be liberated and solubilized. The treatments were as follows: (i) hydrolysis using $0.1 \mathrm{M}$ hydrochloric acid (reflux), suitable to cleave ester bonds, (ii) hydrolysis using $1.0 \mathrm{M}$ hydrochloric acid (reflux), suitable for cleavage of ester and glycosidic linkages, (iii) Björkman lignin, (iv) acidolysis lignin, (v) phosphate buffer, suitable to solubilize proteins and water-soluble polysaccharides, and (vi) $2 \mathrm{M}$ sodium hydroxide (at $50^{\circ} \mathrm{C}$ ), in order to cleave amide linkages (only executed with experiment 2 ). ${ }^{18,33,34}$ The results of the treatments are summarized in Table 2 . Though certain differences were detected between experiments, noticeably similar trends were observed. Treatments ii (1.0 M hydrochloric acid), iv (acidolysis lignin) and vi ( $2 \mathrm{M}$ sodium hydroxide) were most effective concerning release and solubilization of ${ }^{14} \mathrm{C}$ from the plant cell residuum $(65,100$ and $100 \%$, respectively). However, only minor portions of the solubilized radioactivity present in the aqueous treatment solutions could be extracted subsequently with ethyl acetate. This suggests that ${ }^{14} \mathrm{C}$ released from insoluble cell debris consisted of polar or oligomeric material. This assumption was supported, at least partially, by the fact that with treatment vi, a modified work-up (SPE) resulted in a higher recovery of liberated ${ }^{14} \mathrm{C}$ in methanol used for elution.

Both ethyl acetate extracts and aqueous phases remaining after extraction of treatment solutions were examined by TLC for cyprodinil and its primary metabolites. Most of these fractions were also analyzed by HPLC. The results are summarized in Table 2 . It should be added that cyprodinil and its metabolites were only identified by co-chromatography with authentic references, and that only compounds with portions exceeding $0.1 \%$ of ${ }^{14} \mathrm{C}$ applied to the cell cultures are listed in Table 2. Parent cyprodinil was released by procedures $\mathrm{i}$, ii and iii; portions were between 0.1 and $0.3 \%$ of applied ${ }^{14} \mathrm{C}$. Metabolites detected by TLC (Fig 1) were M9 (i), M8 (ii), M2 (ii, iii) and M1 (iii), while portions were low and ranged between 0.1 and $0.2 \%$. Slightly higher percentages of cyprodinil metabolites were released by procedures iv and $\mathrm{v}\left(0.3\right.$ to $2.9 \%$ of applied $\left.{ }^{14} \mathrm{C}\right)$. A number of transformation products were detected by TLC following application of procedure vi (0.5 to $3.1 \%)$, while metabolite M6 was identified by HPLC ( $8 \%$ of applied ${ }^{14} \mathrm{C}$ ). Generally, the unidentified portions of radioactivity were immobile in the TLC examination, or eluted (HPLC) with the front of the solvent $\left(R_{\mathrm{t}}\right.$ 
Table 2. Results from procedures $\mathrm{i}$, ii, iii, iv, v, and vi applied to non-extractable residues of ${ }^{14} \mathrm{C}$-cyprodinil resulting from experiments 1 and $2^{\mathrm{a}, \mathrm{b}, \mathrm{c}}$

\begin{tabular}{lccc}
\hline & Experiment 1 & & Experiment 2 \\
\cline { 3 - 4 } Procedure & $(\%)$ & $(\%)$ & Compounds identified $^{d}$ \\
\hline (i) Hydrolysis with $0.1 \mathrm{M} \mathrm{HCl}$ under reflux & $35(9)$ & $18(2)$ & TLC: cyprodinil, M9e \\
(ii) Hydrolysis with $1.0 \mathrm{M} \mathrm{HCl}$ under reflux & $68(10)$ & $65(8)$ & TLC: cyprodinil, M8, M2 \\
& $12(6)$ & $8(3)$ & HPLC: cyprodinil \\
(iii) Björkman lignin & $99(12)$ & $100(10)$ & TLC: cyprodinil, M1, M2 \\
(iv) Acidolysis lignin & $35(7)$ & $9(1)$ & HPLC: M5 \\
(v) Phosphate buffer; $22^{\circ} \mathrm{C}$ & $\mathrm{f}$ & $100(19) /(80)^{\mathrm{g}}$ & TLC: M1 \\
(vi) Hydrolysis; $2 \mathrm{M} \mathrm{NaOH}, 50^{\circ} \mathrm{C}$ & & TLC: M3, M6, M7, M9 \\
\end{tabular}

\footnotetext{
a $75-200 \mathrm{mg}$ of cell debris was used in each case: $1 \mathrm{mg}$ debris contained $11 \mathrm{~Bq}$ or $91 \mathrm{~Bq}$ for experiments 1 and 2 , respectively (mean of three replicates).

${ }^{b}$ Values in the table are the ${ }^{14} \mathrm{C}$ material solubilized by the respective procedure expressed in terms of percentage of ${ }^{14} \mathrm{C}$ introduced initially, and apply to the supernatant after centrifugation.

${ }^{\mathrm{c}}$ Percentages in parenthesis are the proportions found in ethyl acetate extracts of supernatants (in terms of $\%$ of ${ }^{14} \mathrm{C}$ introduced initially).

${ }^{d}$ Identified by the procedures discussed in the text. Only cyprodinil and those metabolites representing $>0.1 \%$ of applied ${ }^{14} \mathrm{C}$ are listed.

e HPLC was not used here because the amount of radioactivity was too small to be detected satisfactorily.

${ }^{f}$ Not performed.

$g$ From the methanol eluate of the SPE reaction mixture in the modified procedure (vi).
}

ca $2 \mathrm{~min}$ ). This result indicates that-despite the preceding treatment - these portions still possessed polar or oligomeric properties. Discrepancies between TLC and HPLC analysis were frequently observed regarding metabolites identified and portions determined. In addition, data resulting from (similar) hydrolytic procedures $\mathrm{i}, \mathrm{ii}, \mathrm{v}$ and vi partly exhibited inconsistencies. These may be traced back to the lower sensitivity of radio-HPLC compared with radio-TLC, or to chromatographic artefacts during TLC (due to interferences effected by plant components and treatment reagents) leading to incorrect assignment of ${ }^{14} \mathrm{C}$ peaks and, thus, identification of transformation products. However, the results, especially of HPLC analysis, proved that first, both cyprodinil and its metabolites contributed to the fungicide's bound residues, and, second, most of the bound residues (about $12 \%$ of applied ${ }^{14} \mathrm{C}$ ) seemed to be associated with polar or polymeric/oligomeric endogenous material in a considerably stable manner.

As discussed previously, associations between pesticides and insoluble cell components may result from true covalent bonds, simple physico-chemical interactions or entrapment. Procedures for treatment of insoluble cell debris, as those applied in the present investigation (but also others not utilized), may point to the mode of binding of a pesticidal molecule and to its binding site (ie a specific endogenous polymer). However, unequivocal proof for both is generally not obtained. ${ }^{14,16-20}$ For example, if a pesticide and its metabolites are liberated by hydrochloric acid treatment, this may occur as a result of hydrolysis of covalent bonds between xenobiotic molecules and cell polymers, or of hydrolytic cleavage of cell polymers into oligomeric structures and concomitant liberation of entrapped xenobiotics. Findings obtained by treatment with eg acids or bases additionally give valuable hints concerning bioavailability of bound residues. The present results obtained with ${ }^{14} \mathrm{C}$-cyprodinil point to lignin as the main binding site of the non-extractable residues of the fungicide (treatment iv). High solubilization efficiencies observed with hydrolytic procedures ii and vi suggest that cyprodinil metabolites were presumably bound via ester, glycosidic or amide linkages to endogenous polymers. Due to their chemical structures, metabolites $M 1$ to M5, M7, M8, M10 and M11 can form esters or glycosides, whereas M6 and M9 in particular can be bound by amide linkages. M9 and especially M6, were released by amide-cleaving treatment vi. Covalent binding of parent cyprodinil was considered improbable. Thus, we assumed that the fungicide was entrapped and liberated by treatments $\mathrm{i}$, ii and iii. As a whole, the results of treatments $i$ to vi point to a low bioavailability of the non-extractable residues of cyprodinil formed in wheat cell cultures, since only minor amounts of products $M 1$ to $M 11$ and especially parent fungicide were released. However, in order to evaluate the (eco-) toxicological significance of cyprodinil's plant bound residues, data derived from relevant studies using intact plants are indispensable.

\subsection{Experiment 3 with ${ }^{13} \mathrm{C}$-cyprodinil}

The study with ${ }^{13} \mathrm{C}$-cyprodinil was performed parallel to ${ }^{14} \mathrm{C}$ experiment 2 as outlined before. Monitoring of the ${ }^{13} \mathrm{C} /{ }^{12} \mathrm{C}$ ratio during four growth cycles of the wheat cells on ${ }^{13} \mathrm{C}$-depleted glucose (99.9 atom\% ${ }^{12} \mathrm{C}$ ) demonstrated maximum ${ }^{13} \mathrm{C}$ depletion with regard to the insoluble endogenous cell components. In detail, the corresponding data were as follows: $\delta=-660( \pm 15) \%$ o after the first, $\delta=-825( \pm 2) \%$ o after the second, $\delta=-850( \pm 10) \%$ o after the third and $\delta=-827( \pm 1) \%$ after the fourth growth cycle. Consequently, the ${ }^{13} \mathrm{C}$ content of the wheat cells (as determined with the untreated assay) was about $0.10 \%$ 
after four growth cycles, whereas $1.11 \%$ is commonly given as the natural abundance of this carbon isotope.

After extraction of the wheat suspensions incubated with ${ }^{13} \mathrm{C}$-cyprodinil, cell debris was collected and airdried. The weight of the combined debris amounted to about $4.8 \mathrm{~g}$. A sample ( $c a 150 \mathrm{mg}$ ) of the debris was examined by ${ }^{13} \mathrm{C}-\mathrm{CP} / \mathrm{MAS}$ NMR spectroscopy; similarly, a sample of the untreated ${ }^{13} \mathrm{C}$-depleted assay was analyzed. The results shown in Figs 2 and 3, respectively, demonstrated that considerably similar spectra were obtained, and that no distinct ${ }^{13} \mathrm{C}$ peaks, which could unequivocally be traced back to the applied ${ }^{13} \mathrm{C}$-cyprodinil, emerged in the spectrum derived from the fungicide treated cells. The results of ${ }^{14} \mathrm{C}$ experiment 2 discussed before showed that cyprodinil and several metabolites, especially transformation product M6, contributed to the bound residues of the fungicide. Table 3 shows the ${ }^{13} \mathrm{C}$ NMR shifts of carbon $\mathrm{C} 2$ of $\left[2-\right.$ pyrimidyl $\left.-{ }^{13} \mathrm{C}\right]$ cyprodinil and of the corresponding carbon atoms of metabolites M1 to M11. All were determined in solution, but similar shifts resulted from solid-state ${ }^{13} \mathrm{C}$ NMR (data not shown). Thus, in the study using [2-pyrimidyl${ }^{13} \mathrm{C}$ ]cyprodinil, ${ }^{13} \mathrm{C}$ peaks at about $160 \mathrm{ppm}$ were expected. Recycling of cyprodinil-derived ${ }^{13} \mathrm{C}$ via (natural) one- or two-carbon fragments into natural polymeric cell components exhibiting chemical shifts prevailingly below $100 \mathrm{ppm}$ (such as cellulose, pectin) was excluded, since reasonable recoveries of ${ }^{14} \mathrm{C}$ were observed in experiments 1 and 2 (105.30 and 93.16\%, respectively). Evolution and loss of ${ }^{14} \mathrm{C}$-carbon dioxide was considered as an inevitable concomitant of extensive degradation of the ${ }^{14} \mathrm{C}$-labelled fungicide.

In order to explain the absence of any ${ }^{13} \mathrm{C}$ cyprodinil-derived peaks in the solid-state ${ }^{13} \mathrm{C}$ NMR spectrum of the sample obtained from the treated cells, we made the following rough estimate. A total of $4.8 \mathrm{mg}$ of ${ }^{13} \mathrm{C}$-cyprodinil was applied to 24 assays of the wheat suspensions. About $20 \%$ of this amount (based on parent fungicide) was present in $4.8 \mathrm{~g}$ of extracted cell residuum. Consequently,

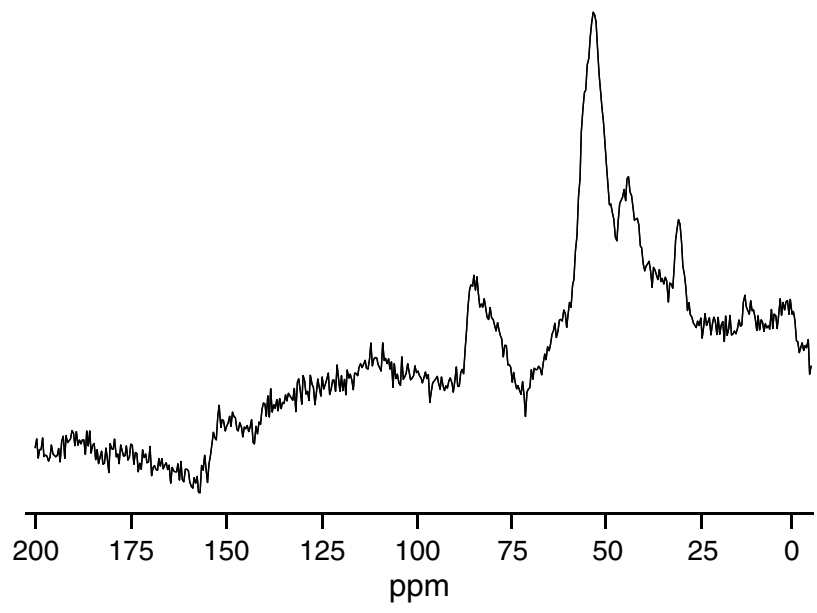

Figure 2. Solid-state(CP/MAS), proton-decoupled (WALTZ) ${ }^{13} \mathrm{C} N M R$ spectrum of ${ }^{13} \mathrm{C}$-depleted insoluble debris of wheat cells treated with ${ }^{13} \mathrm{C}$-cyprodinil (recorded at $125.80 \mathrm{MHz}$ ).

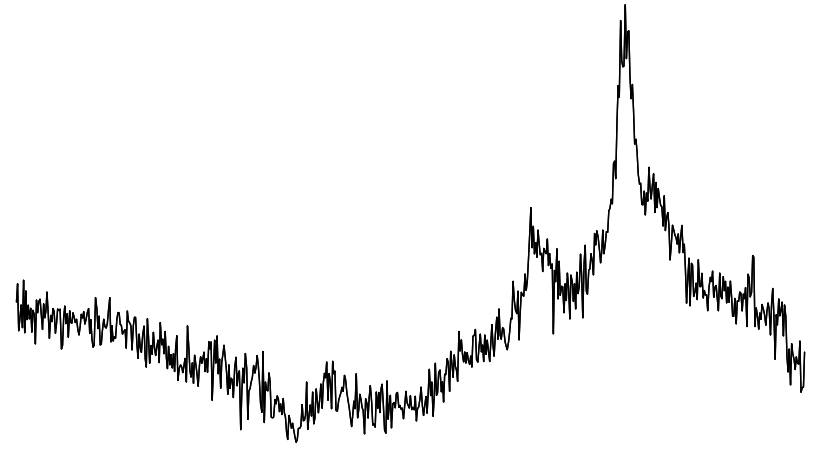

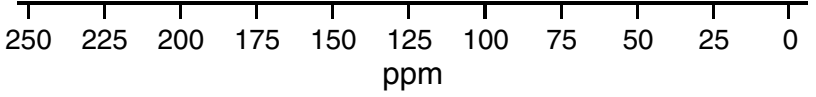

Figure 3. Solid-state (CP/MAS), proton-decoupled (WALTZ) ${ }^{13} \mathrm{C}$ NMR spectra of ${ }^{13} \mathrm{C}$-depleted insoluble debris of wheat cells (recorded at $125.80 \mathrm{MHz}$ ).

Table 3. ${ }^{13} \mathrm{C}$ NMR shifts (in ppm relative to tetramethylsilane) of carbon $\mathrm{C} 2$ of [2-pyrimidyl- $\left.{ }^{13} \mathrm{C}\right]$ cyprodinil and of corresponding carbon atoms of cyprodinil metabolites $\mathrm{M} 1-\mathrm{M} 11^{\mathrm{a}}$

\begin{tabular}{lcc}
\hline Compound & $\begin{array}{c}\text { Chemical shift } \\
(\text { ppm })\end{array}$ & Solvent \\
\hline Cyprodinil & 159.7 & $\mathrm{CDCl}_{3}$ \\
M1 & 159.3 & $\mathrm{DMSO}_{6}$ \\
M2 & 159.6 & $\mathrm{DMSO}_{6} d_{6}$ \\
M3 & 160.2 & $\mathrm{CDCl}_{3}$ \\
M4 & 159.9 & $\mathrm{CDCl}_{3}$ \\
M5 & 158.6 & $\mathrm{CDCl}_{3}$ \\
M6 & 162.9 & $\mathrm{CDCl}_{3}$ \\
M7 & 157.6 & $\mathrm{DMSO}_{6}$ \\
M8 & 159.2 & $\mathrm{CDCl}_{3}$ \\
M9 & 161.1 & $\mathrm{DMSO}_{6} d_{6}$ \\
M10 & 155.8 & $\mathrm{DMSO}_{6}$ \\
M11 & 159.7 & $\mathrm{DMSO}_{6}$ \\
\hline
\end{tabular}

a See Fig 1 for chemical structures.

$150 \mathrm{mg}$ of cell debris (NMR sample) contained $30 \mu \mathrm{g}$ (equal to $0.133 \mu$ moles) cyprodinil, or $8 \times 10^{16}$ spins of ${ }^{13} \mathrm{C}$-labelled carbon atom $\mathrm{C} 2$. Regarding ${ }^{13} \mathrm{C}$ background, it was assumed that the cell residuum consisted only of glucose monomers. Thus, $150 \mathrm{mg}$ of the debris contained 0.83 mmoles glucose or 4.98 mmoles of carbon atoms. Due to the ${ }^{13} \mathrm{C}$ depletion procedure, $4.98 \mu$ moles of these consisted of carbon isotope ${ }^{13} \mathrm{C}$, corresponding with $2.99 \times 10^{18}$ spins. We concluded that both the low amount of spins derived from ${ }^{13} \mathrm{C}$-cyprodinil and the 37 -fold excess of ${ }^{13} \mathrm{C}$ spins originating from the ${ }^{13} \mathrm{C}$-depleted cell residuum were responsible for the failure of solid-state ${ }^{13} \mathrm{C}$ NMR regarding characterization of the non-extractable residues of cyprodinil. While no peaks of ${ }^{13} \mathrm{C}$-cyprodinil were observed, weak signals of insoluble cell materials emerged (Figs 2 and 3). According to published data, these can be referred to proteins, carbohydrate polymers, such as cellulose and lignin. $28,29,31,35$

The insoluble cell debris of experiment $3\left({ }^{13} \mathrm{C}-\right.$ cyprodinil) was subjected to treatments $\mathrm{i}$ to vi as 
outlined with experiments 1 and $2\left({ }^{14} \mathrm{C}\right.$-cyprodinil). It was anticipated that the treatments would, first, further reduce amounts of ${ }^{13} \mathrm{C}$ derived from natural cell components, and, second, make possible the recording of spectra of corresponding samples as solutions in appropriate solvents. Liquid ${ }^{13} \mathrm{C}$ NMR spectra of all samples were recorded. Occasionally however, materials remaining in aqueous treatment solutions and those contained in their ethyl acetate extracts were re-combined for spectroscopy. Figure 4 shows the ${ }^{13} \mathrm{C}$ NMR spectra obtained after application of treatments ii, iii, iv, and v. All other spectra recorded gave no utilizable results; only solvent signals were observed. Peaks of cellular components, such as those detected in the solid-state ${ }^{13} \mathrm{C}$ NMR spectra discussed before, were generally absent from all of the liquid spectra; at least so far, procedures i to vi were successful.

Besides signals of NMR solvents methanol and dioxane or contaminating solvents (acetone, methanol), peaks were detected in the spectra shown in Fig 4 at about $25 \mathrm{ppm}$ (not specifically marked; treatment v), at about $99 \mathrm{ppm}$ (ii, iii, iv) and at $164-165 \mathrm{ppm}$ (ii, iii, v). The origin of peaks at $25 \mathrm{ppm}$ and $99 \mathrm{ppm}$ remained unknown; due to their chemical shifts, they can not be referred to covalently bound or free cyprodinil or metabolites M1-M11 (Table 3). As discussed before, recycling of cyprodinil-derived ${ }^{13} \mathrm{C}$ into insoluble natural cell components was excluded. The peaks at $25 \mathrm{ppm}$ and $99 \mathrm{ppm}$ were possibly signals

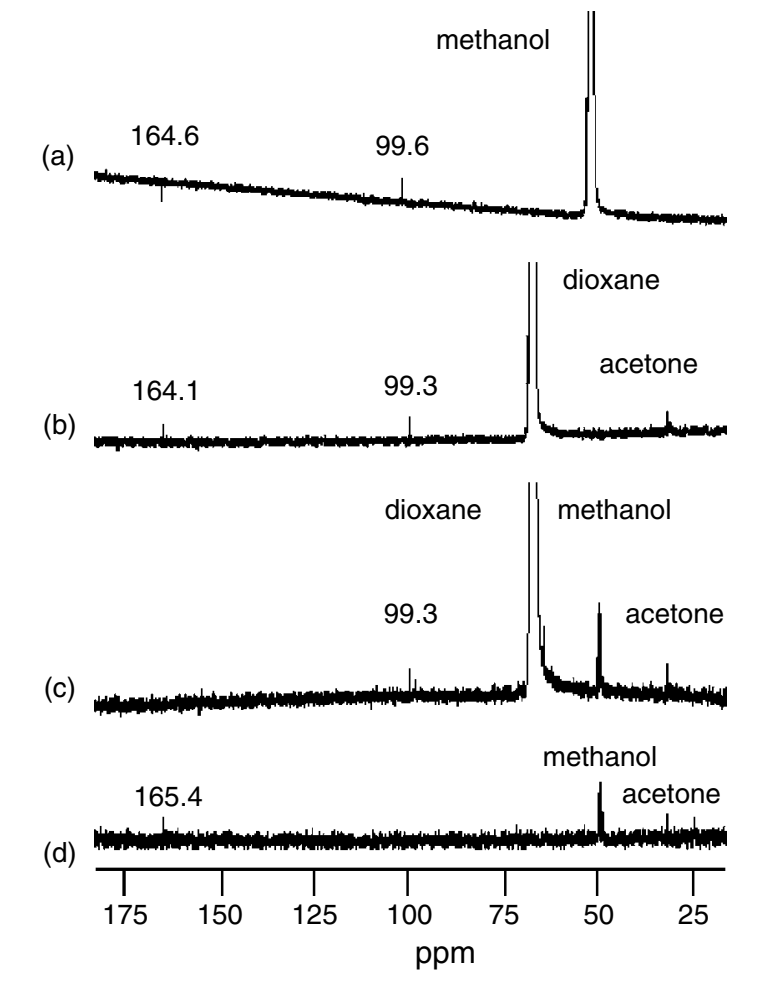

Figure 4. Liquid, proton-decoupled (WALTZ) ${ }^{13} \mathrm{C}$ NMR spectra of fractions prepared from ${ }^{13} \mathrm{C}$-depleted insoluble debris of wheat cells treated with ${ }^{13} \mathrm{C}$-cyprodinil (recorded at $75.5 \mathrm{MHz}$ ); a: treatment ii $(1 \mathrm{M}$ $\mathrm{HCl}$, reflux), aqueous phase remaining after extraction with ethyl acetate; b: treatment iii (Björkman lignin); c: treatment iv (acidolysis lignin); d: treatment $v$ (phosphate buffer), aqueous phase remaining after extraction with ethyl acetate. of unknown contaminants of solvents and reagents utilized for treatment of the cell debris. In contrast, the peaks observed at about $165 \mathrm{ppm}$ emerged at chemical shifts expected for cyprodinil and its metabolites (M1-M11). These signals, however, appeared in fractions derived from treatments exhibiting both high (ii) and low efficiency (iii, v) with regard to solubilization of cyprodinil-derived bound residues (cf Table 2). In addition, in ${ }^{13} \mathrm{C}$ NMR spectra of samples derived from highly effective treatments iv (Fig 3) and vi (amide cleavage; not shown) no signals emerged at $165 \mathrm{ppm}$. It should be added that, as discussed before, noticeably high portions of metabolite M6 were detected in experiment 2 with ${ }^{14} \mathrm{C}$-cyprodinil after treatment vi. These inconsistent findings as a whole (ie between ${ }^{13} \mathrm{C}$ and ${ }^{14} \mathrm{C}$ experiments, as well as among different treatments of cell debris of the ${ }^{13} \mathrm{C}$ experiment) left serious doubts whether the peaks observed at about $165 \mathrm{ppm}$ originated from cyprodinil or products $M 1-M 11$. The failure of liquid ${ }^{13} \mathrm{C}$ NMR spectroscopy was attributed to low amounts of corresponding spins present in the samples. Increasing the amounts of ${ }^{13} \mathrm{C}$ spins contained in the NMR tubes proved to be impossible experimentally, due to the low solubility of the samples obtained from treatments $i$ to vi in small volumes of NMR solvents. Separation of cyprodinilderived ${ }^{13} \mathrm{C}$ from natural materials present in samples was considered unfeasible because of the nature of the fungicide's bound residues formed in the wheat cell suspension cultures. Recently, soil bound residues of ${ }^{13} \mathrm{C}$-cyprodinil were successfully characterized by ${ }^{13} \mathrm{C}$ NMR spectra. ${ }^{26}$ Judged from the data reported, higher concentrations of the fungicide $\left(500 \mathrm{mg} \mathrm{kg}^{-1}\right)$ compared with the present study were applied to the soil. Consequently, higher amounts of ${ }^{13} \mathrm{C}$-cyprodinilderived bound residues (about 10-fold compared with present data) were obtained, which, in view of the method of preparation of samples, were presumably contaminated with considerably lower amounts of natural organic soil materials.

\section{CONCLUSION}

In the present investigation, non-extractable residues of the fungicide cyprodinil formed in cell suspension cultures of wheat were examined using both ${ }^{14} \mathrm{C}$ and ${ }^{13} \mathrm{C}$-labelled cyprodinil. The main objective was to ascertain whether ${ }^{13} \mathrm{C}$ NMR spectroscopy could be utilized to characterize the bound residues of the fungicide. The experiments with ${ }^{14} \mathrm{C}$-labelled cyprodinil revealed that cyprodinil and metabolites of the compound contributed to formation of bound residues (about $20 \%$ of applied ${ }^{14} \mathrm{C}$ ). More than $50 \%$ of the non-extractable radioactivity was bound in a considerably stable manner to endogenous components and could not be liberated by acid or base. In the study with ${ }^{13} \mathrm{C}$-cyprodinil and ${ }^{13} \mathrm{C}$ depleted suspensions, examination of the insoluble cell residuum and solubilized fractions of it by solidstate and liquid ${ }^{13} \mathrm{C}$ NMR spectroscopy, respectively, 
gave no utilizable or unambiguous results. In addition, the spectra exhibited large inconsistencies concerning the data obtained from the conventional ${ }^{14} \mathrm{C}$ experiments. We concluded that, due to the low amounts of ${ }^{13} \mathrm{C}$ spins present in comparably large quantities of insoluble plant components, ${ }^{13} \mathrm{C}$ NMR spectroscopy (as performed in the present study) appears to be unsuited for characterization and (eco-) toxicological evaluation of non-extractable residues of pesticides. This also holds true if plant tissues used for experiments are maintained under ${ }^{13} \mathrm{C}$-depleting conditions.

\section{ACKNOWLEDGEMENTS}

The authors thank Hildegard Patti and Brigitte Thiede for establishment and maintenance of the wheat suspension culture grown on glucose, Marko Bertmer and Holger Kühn (Department of Macromolecular Chemistry, RWTH Aachen University) for assistance with the NMR spectroscopy, Novartis (now Syngenta) for providing ${ }^{14} \mathrm{C}$ - and ${ }^{13} \mathrm{C}$-cyprodinil as well as nonlabelled reference compounds and expertise, and Mrs A Seraphin (Institute of Hydrobiology and Fishery Science, University of Hamburg, Germany) for determination of the ${ }^{13} \mathrm{C} /{ }^{12} \mathrm{C}$ ratios. The investigation was supported by the Deutsche Forschungsgemeinschaft (DFG; grants: Scha 390/2-1 and 390/2-2).

\section{REFERENCES}

1 Roberts TR, Non-extractable pesticide residues in soils and plants. Pure Appl Chem 56:945-956 (1984).

2 Kearney PC, IUPAC pesticide commission report: definition of pesticide residues in plants and soil. $\mathcal{F A O A C}$ 65:1030-1032 (1982).

3 Kacew S, Akhtar $\mathrm{MH}$ and Khan SU, Bioavailability of bound pesticide residues and potential toxicologic consequences - an update. Proc Soc Exp Biol Med 211:62-68 (1996).

4 Akhtar MH, Khan SU and Kacew S, Bioavailability of bound pesticide residues and potential toxicologic consequences. Proc Soc Exp Biol Med 199:12-21 (1992).

5 Lu AYH, Lee Chiu S-H and Wislocki PG, Development of a unified approach to evaluate the toxicologic potential of bound residues. Drug Metab Rev 22:891-904 (1990).

6 Kovacs MF Jr, Regulatory aspects of bound residues (chemistry). Res Rev 97:1-17 (1986).

7 Skidmore MW, Paulson GD, Kuiper HA, Ohlin B and Reynolds S, Bound xenobiotic residues in food commodities of plant and animal origin. Pure Appl Chem 70:1423-1447 (1998).

8 Skidmore MW, Paulson GD, Kuiper HA, Ohlin B and Reynolds S, Extended Summary of IUPAC Technical Report 40: Bound xenobiotic residues in food commodities of plant and animal origin. Pest Manag Sci 58:313 (2002).

9 Commission of the European Communities (Directorate General for Agriculture VI B II-1), Metabolism and distribution in plants, 7028/VI/95 rev 3 (1997).

10 Commission of the European Communities (Directorate General for Agriculture VI B II-1), General recommendations for the design, preparation and realization of residue trials, 7029/VI/95 rev 5 (1997).

11 Commission of the European Communities (Directorate General for Agriculture VI B II-1), Processing studies. 7035/VI/95 rev 5 (1997)
12 United States Environmental Protection Agency (Prevention, Pesticides and Toxic Substances), EPA Residue chemistry guidelines: OPPTS 860.1300 Nature of the residue-plants, livestock, EPA 712-C-95-172 (1995).

13 Donzel B and Dorn E, Appraisal of the fate of agrochemicals in plants and soil: a cost-effective integrated approach. Pure Appl Chem 64:1965-1976.

14 Schmidt B, Non-extractable residues of pesticides and xenobiotics in plants. Rec Res Dev Agric Food Chem 3:329-354 (1999).

15 Commission of the European Communities (Directorate General for Agriculture VI B II-1), Livestock feeding studies, 7031/VI/95 rev 4 (1996).

16 Sandermann H Jr., Hertkorn N, May RG and Lange BM, Bound pesticidal residues in crop plants: chemistry, bioavailability, and toxicology, in Pesticide biotransformation in plants and microorganisms - similarities and divergences, ed by Hall JC, Hoagland RE and Zablotowicz RM, American Chemical Society, Washington, DC, USA, pp 119-128 (2001).

17 Lamoureux GL and Rusness DG, Xenobiotic conjugation in higher plants, in Xenobiotic conjugation chemistry, ed Paulson GD, Caldwell J, Hutson DH and Menn JJ, American Chemical Society, Washington, DC, USA, pp 62-105 (1986).

18 Langebartels $\mathrm{C}$ and Harms H, Analysis for nonextractable (bound) residues of pentachlorophenol in plant cells using a cell wall fractionation procedure. Ecotoxicol Environ Saf 10:268-279 (1985).

19 Pillmoor JB, Gaunt JK and Roberts TR, Examination of bound (non-extractable) residues of MCPA and flamprop in wheat straw. Pestic Sci 15:375-381 (1984).

20 Sandermann H Jr, Scheel D and von der Trenck T, Metabolism of environmental chemicals by plants - copolymerization into lignin. F Appl Polym Sci Appl Polym Symp 37:407-420 (1983).

21 Heye UJ, Speich J, Siegle H, Steinemann A, Forster B, KnaufBeiter G, Herzog J and Hubele A, CGA 219417: a novel broad-spectrum fungicide. Crop Prot 13:541-549 (1994).

22 Masner P, Muster P and Schmid J, Possible methionine biosynthesis inhibition by pyrimidinamine fungicides. Pestic Sci 42:163-166 (1994).

23 Tomlin C (ed), The Pesticide Manual, The British Crop Protection Council and The Royal Society of Chemistry, Surrey and Cambridge, UK, pp 161-162 (1994).

24 Roberts TR and Hutson DH, Metabolic pathways of agrochemicals. Part 2: Insecticides and fungicides, The Royal Society of Chemistry, Cambridge, UK, pp 963-965 (1999).

25 Nicollier $G$ and Donzel B, Release of bound ${ }^{14} \mathrm{C}$-residues from plants and soil using microwave extraction, in Options 2000-Eighth IUPAC International Congress of Pesticide Chemistry, Book of Abstracts Vol 2, American Chemical Society, Washington, DC, USA, p 961 (1994).

26 Dec J, Haider K, Benesi A, Rangaswamy V, Schäffer A, Plücken U and Bollag J-M, Analysis of ${ }^{13} \mathrm{C}-$ labeled fungicide cyprodinil by NMR spectroscopy. Environ Sci Technol 31:1128-1135 (1997)

27 Dec J, Haider K, Benesi A, Schäffer A, Fernandes E and Bollag J-M, Analysis of ${ }^{13} \mathrm{C}$-labeled fungicide cyprodinil by NMR spectroscopy. Environ Sci Technol 31:2991-2997 (1997).

$28 \mathrm{Ha}$ M-A, Jardine WG and Jarvis MC, Solid-state ${ }^{13} \mathrm{C}-\mathrm{NMR}$ of cell walls in wheat bran. $\mathcal{F}$ Agric Food Chem 45:117-119 (1997).

29 Leary GJ and Newman RH, Cross polarization/magic angle spinning nuclear magnetic resonance (CP/MAS NMR), in Methods in lignin chemistry, ed by Lin SY and Dence CW, Springer-Verlag, Berlin, Germany, pp 146-161 (1992).

30 Robert D, Carbon-13 nuclear magnetic resonance spectrometry, in Methods in lignin chemistry, ed by Lin SY and Dence CW, Springer-Verlag, Berlin, Germany, pp 250-273 (1992).

31 Atalla RH and Vanderhart DL, The role of ${ }^{13} \mathrm{C}-\mathrm{NMR}$ spectroscopy in studies of the nature of native celluloses. Solid State Nucl Mag Reson 15:1-19 (1999). 
32 Schmidt B, Metabolic profiling using plant cell suspension cultures, in Pesticide biotransformation in plants and microorganisms - similarities and divergences, ed by Hall JC, Hoagland RE and Zablotowicz RM, American Chemical Society, Washington, DC, USA, pp 40-56 (2001).

33 Locke RK, Bastone VB and Baron RL, Studies of carbamate pesticide metabolism utilizing plant and mammalian cells in culture. F Agric Food Chem 19:1205-1209 (1971).
34 Rosa N and Neish AC, Formation and occurrence of $\mathrm{N}$ malonylphenylalanine and related compounds in plants. Canad F Biochem 46:797-806 (1968).

35 Maciel GE, Haw JF, Smith DH, Gabrielsen BC and Hatfield GR, Carbon-13 nuclear magnetic resonance of herbaceous plants and their components, using cross polarization and magic-angle spinning. F Agric Food Chem 33:185-191 (1985) 